\title{
Haunted Walks of District Six: Propositions for Counter-Surveying
}

Qualitative Inquiry

2022, Vol. 28(2) 244-256

(c) The Author(s) 2021

Article reuse guidelines:

sagepub.com/journals-permissions

DOI: $10.1177 / 10778004211042349$

journals.sagepub.com/home/qix

@SAGE

\author{
Siddique Motala' $\left(\mathbb{D}\right.$ and Vivienne Bozalek ${ }^{2}$ (D)
}

\begin{abstract}
This article traces a pedagogical trajectory in South African higher education that started in engineering education and leads to walking-as-research. Situated on District Six, a well-known site of apartheid forced removals, a cartographic and diffractive methodology is utilized to trace the development of this pedagogy, as well as walks that have emerged out of mapping the site by means of geographic information system (GIS). We develop propositions related to a practice we call counter-surveying, and we trace two walks of District Six with people who are connected to the site. Recognizing the hauntological power of walking, we walk into the past and diffractively read the walks together with South African history, geomatics education, and posthumanist theory. Premised on relational ontologies, we attend to the ghosts of District Six and explore different ways of interrogating issues of land and education, while opening up a space for Otherness.
\end{abstract}

\section{Keywords}

cartography, posthumanism, walking methodology, counter-surveying, transdisciplinary activism

\section{Introduction}

Being the most famous site of apartheid forced removals, District Six is a mythical place, almost a non-place. For many years, it has been a striking memorial to the vicious apartheid system, because it consisted of open, unused land close to the city center of Cape Town. In 1966, District Six was declared a Whites-only area, and by the early 1980s, more than sixty thousand people were forcibly removed to far-flung suburbs and townships (some would later become notorious ghettos) on the outskirts of Cape Town. Their houses, shops, markets, cinemas, and all other buildings in the District were destroyed by apartheid bulldozers. Only a few buildings and rubble remained. Today, much of District Six is still barren rubble, but it is changing. After years of contestation and politicking, the post-apartheid government's land reform policy is resulting in some of the old residents of District Six (or their descendants) being returned to newly built accommodation. When we speak to people in Cape Town about District Six, many have a connection to it-Usually, it is a place that a family member was (removed) from. It is not a neutral space - as a haunted and contested space, it is intensely affective.

In this article, we map the development of Siddique's pedagogy, which started in geomatics education and has escaped the confines of engineering education to be transformed into haunted walks of District Six. We focus on two walks of District Six and read these walks with feminist new materialist/posthumanist theory and geomatics. These diffractions help us to develop propositions related to a walking practice we call counter-surveying. For the purposes of this article, counter-surveying involves using surveying and mapping techniques to find and mark the locations of sites that no longer physically exist. The marks are impermanent and serve to supplement the experience of moving through the space. The experience also contributes to collective, embedded, and embodied knowledge-making practices at the local level, and focuses on the needs of the dispossessed and marginalized.

Figure 1 is a map produced with geographic information system (GIS), and shows the outline of District Six in a black-and-white dashed line. This area was declared a Whites-only area under the Group Areas Act in 1966. The aerial imagery that forms the backdrop was taken in 2019. It can be observed that large parts of District Six are open land. In the two small inset maps, the location of two houses that

\footnotetext{
'University of Cape Town, South Africa

${ }^{2}$ University of the Western Cape, Cape Town, South Africa

Corresponding Author:

Siddique Motala, Department of Civil Engineering, University of Cape Town, Private Bag X3, Rondebosch, 770I, Cape Town, South Africa. Email: siddique.motala@uct.ac.za
} 


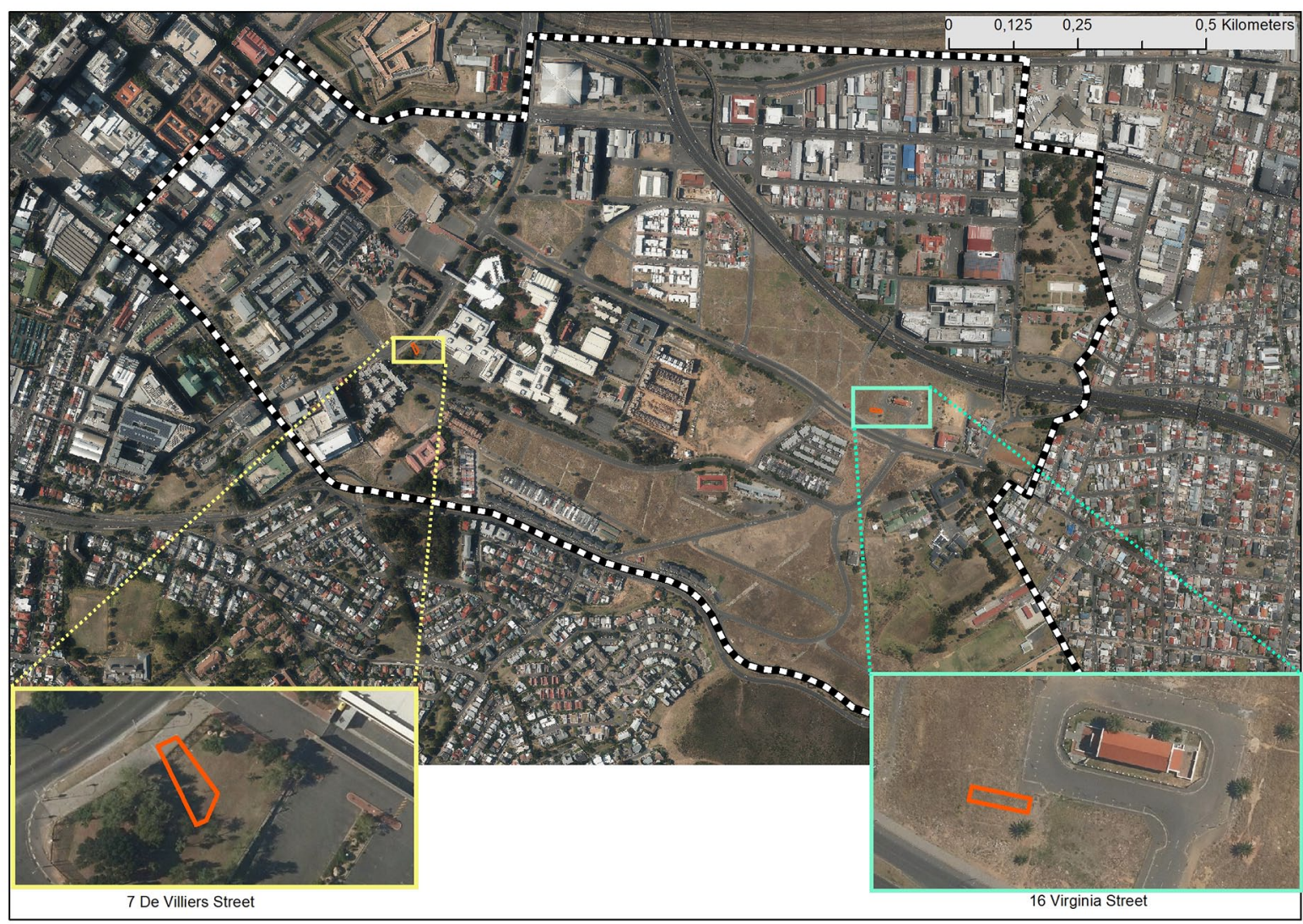

Figure I. District Six, 2019.

were destroyed is shown. The inset map on the left shows the location of 7 De Villiers Street, and the inset map on the right shows the location of 16 Virginia Street. Both these "houses" were visited during walks that we report on here.

Until recently, Siddique was a lecturer at the Cape Peninsula University of Technology (CPUT), teaching surveying and GIS to geomatics students in the engineering faculty. He used to conduct surveying and GIS teaching on the District Six campus, which is situated in the middle of the historic site of District Six. In Figure 1, the white buildings to the east of 7 De Villiers Street are the buildings of CPUT. The campus covers about $10 \%$ of the area of District Six and was built in the mid-1980s.

Figure 2 is a similar map to Figure 1 and covers the same geographical space, but the backdrop is an aerial image from 1968. It can be seen that most of the original buildings of District Six are still intact, apart from the area to the east of 7 De Villiers Street, where some of the first demolitions took place in 1968. The other newly demolished area was above 16 Virginia Street, to make way for the construction of the N2 highway. The two inset maps show the houses pre-demolition. These houses were the ancestral homes of our fellow walkers, Rose-Anne and Joe.

\section{Cartographies}

There are two conceptions of cartography that we utilize:

1. A preferred analytical method of some posthumanist scholars to map a set of material and discursive conditions. For Braidotti (2002),

A cartography is a theoretically-based and politicallyinformed reading of the present. ... [I]t responds to my two main requirements, namely to account for one's locations in terms both of space (geo-political or ecological dimension) and time (historical and genealogical dimension). (p. 2)

2. The traditional geomatics-related notion which refers to the science and practice of making maps that are based on the representation of spatial location. According to the South African national mapping agency,

Cartography or mapmaking is the study and practice of making maps. Map making involves the application of both scientific and artistic elements, combining graphic 


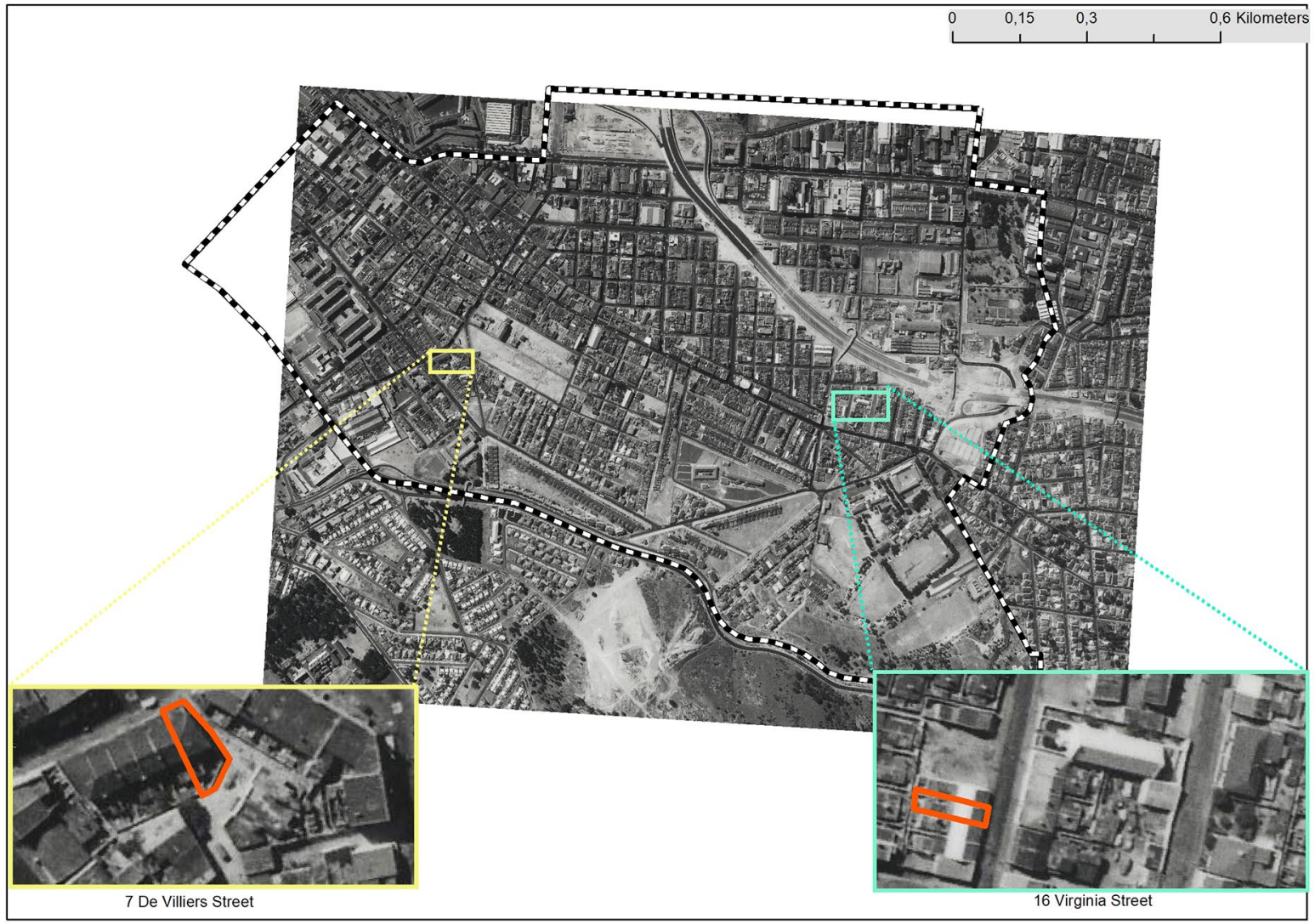

Figure 2. District Six, 1968.

talents and specialized knowledge of compilation and design principles ... Maps function as visualization tools for spatial data. (National Geo-Spatial Information, n.d.)

Cartography (1) above emerged out of the (post-)humanities and is a way for critical theorists to depict situated historical locations. On the contrary, cartography (2) is science-based, with representational, positivist, capitalist, and humanist hauntings. In geomatics practice, surveying and cartography are closely related-A surveyor captures spatial data that are represented by means of cartography. In this article, we explore counter-cartography (also called counter-mapping) and counter-archiving, and propose a type of surveying that we call counter-surveying.

This analysis emerged out of geomatics education, and there are resonances and dissonances between both the geomatics and posthumanist cartographies. As part of our posthumanist methodology, we employ diffraction (Barad, 2007) to put both cartographies into conversation with each other, while we walk through the past/present/future on the land of District Six, from which we experiment with a new practice of counter-surveying.
For Barad (2007), diffraction is used as a methodology which engages affirmatively with difference. It calls forth a different kind of scholarship to pitting one viewpoint against another, offering instead a generous stance which does not dismiss one theory, text, discipline, or practice from the standpoint of the other. Diffraction as a methodology is used to trace entanglements and how they matter, as well as mapping the effects of difference. Tracing entanglements, we note that the walks and the mapping of the site by means of GIS are co-constitutive and iterative. We propose that walking the site of District Six while holding a posthumanist sensibility provides the impetus for surprising possibilities, such as the development of the practice of counter-surveying.

A diffractive methodology is non-representationalist (MacLure, 2013) in that it does not reflect the world from the outside but assumes that we are part of the world, entangled in it, and implicated in everything and unable to extricate ourselves. This non-representational viewpoint is potentially problematic within geomatics, which relies heavily on the logic of representation. However, we will show that by utilizing certain aspects of surveying and 
mapping, and harnessing a non-representational sensibility, new forms of knowledge production can emerge. Diffraction allows us to bring together potentially divergent views which matter. Barad (2007) notes that the point of diffraction "is to provide a transdisciplinary approach that remains rigorously attentive to important details of specialized arguments within a given field, in an effort to foster constructive engagements across (and a reworking of) disciplinary boundaries" (p. 25)

\section{Our Positionalities}

We have worked on this article together/apart. Some aspects were done collaboratively, such as most of the writing and one of the walks that we report on here. Even though we use autobiographical stories (ours and our fellow walkers') as part of various practices (such as walking and counter-surveying), these practices are diffractively constructed. Stories are important in the context of District Six, and our agential cut grants agency to specific stories which serve to critique hegemonic power structures. Our stories help to negotiate complexity, often from the standpoint of marginalized Others. Our subjectification is multiple and often contradictory. In addition, by telling our stories as we traverse District Six, we are telling stories of the ancestors who experienced District Six in multiple ways, and who continue to haunt the site today. Following Thrift (2008), we do not believe that lives are meant to be known and understood - It would be more useful to describe and re-describe them to trace complex and contradictory entanglements.

\section{Siddique}

I was born and raised in Durban, and lived through apartheid in the 1970s, 80s and early 90s there. Although I was not in District Six during the time of forced removals, the story of District Six is my story too. Being differentially marked as "Indian South African," I lived in an Indian-only group area in Durban, and some of my family were subject to the violence and humiliation of dispossession and forced removal. As an Other, I occupy a liminal space-culturally, historically, academically and physically. Walking the site of District Six has always been a haunting experience.

\section{Vivienne}

I am an Emerita Professor in Women's and Gender Studies at the University of the Western Cape, an Historically Black University (HBU), where I have worked for the past thirty years. I grew up in apartheid South Africa in a privileged position due to my classification as "White" by a state which confiscated and expropriated resources from those categorized as Black and made available land, buildings, education, health and welfare services and cultural amenities specifically for Whites only.
We have been conducting research together for the last 8 years, and our common interest in posthumanism, which emphasizes movement, experimentation, and ethical practice, has inspired us to think about social justice, pedagogy, and walking together through District Six.

\section{A Cartography of the Walks of District Six}

One afternoon 15 years ago, Siddique left his office at CPUT and was walking back to his car when a haunting happened. He stopped, looked up at Table Mountain, and realized that he was walking on the land of District Six. The questions that immediately came to mind were as follows: What was here before? Exactly here-where I am standing right now? He then realized that he could answer the questions by using the techniques and technologies that he taught.

Siddique's original aim was to carefully assimilate maps and spatial data of District Six, to create an accurate cartographic archive. This would ensure that any surveying work to re-locate historical buildings would be as accurate as possible. Accuracy, after all, is central to the subjectification of geomatics practitioners, who ascribe to professional ethics (Motala, in press). Characteristics such as individuality, reliability, professional conduct, and legality are favored by Western humanism, and dominate the assemblage out of which the subjectivities of geomatics students and practitioners emerge. The posthuman subject, on the contrary, is complex, non-linear, non-unitary, relational, embodied, and embedded (Braidotti, 2006). This subject is connected to a web of human and non-human agents via dynamic power relations, thus problematizing the notion of a singular, stable essence.

The essence of cartography was sought by Western academics in the 1960s and 1970s, and they focused on "the flow of data from the world through the map to the user" (Edney, 2011, p. 308) as if the underlying world is an unambiguous, single, discrete entity. This is the underlying premise of surveying - There is a stable ground "out there," an inert backdrop against which we go about our everyday lives, that can be measured by surveying and represented cartographically.

A diffractive reading helps us to understand how the practice of surveying/mapping gets co-constituted with the creation of the world. What gets mapped, therefore what gets surveyed, is dependent on specific (ostensibly scientific) factors such as accuracy and scale. There is a Cartesian cut being enacted-The surveyor-as-subject surveys the land-as-object and then represents it on a map through the act of mapping. Western culture has a deeply entrenched faith in representationalism. Barad (2007) points out that

the asymmetrical faith we place in our access to representations over things is a historically and culturally contingent belief that 
is part of Western philosophy's legacy and not a logical necessity; that is, it is simply a Cartesian habit of mind. It takes a healthy scepticism toward Cartesian doubt to be able to see an alternative. (p. 49)

As an alternative, a posthumanist ontology challenges the land-as-backdrop view, and recognizes that specific procedures, methods of observation and practices produce the world. Thrift (2008) reminds us that non-representational theory is about performance, practice, and movement, as opposed to representation. This shift from representation to performance requires a disidentification from White, Western, rationalist, humanist, and anthropocentric hierarchies, all of which are strongly enforced in the geomatics knowledge base.

Geomatics is overwhelmingly focused on technical issues, and geomatics practitioners often believe that they are observers who are largely disconnected from political issues. However, surveyors do not stand at a distance and represent something "out there"; rather, surveyors are part of the materiality of the world that is being surveyed. Surveyors and their maps played a role in the destruction of District Six, as did architects, planners, engineers, and politicians. J. B. Harley points out that what is shown on the map is not a representation of a pre-existing world, but it helps to construct the world. According to Harley (1990), "maps represent the world through a veil of ideology, are fraught with internal tensions, provide classic examples of power-knowledge, and are always caught up in wider political contexts" (p. 1).

As Barad (2007) points out, "practices of knowing are specific material engagements that participate in (re)configuring the world" (p. 91). Siddique slowly realized that traditional surveying and mapping practices, with their representational underpinnings, were unsatisfactory as analytical tools in a haunted place like District Six. He kept surveying, mapping, and representing different aspects of District Six over the years. All the maps of District Six that he and his students found were digitized and imported into a GIS archive. Locations of important sites in District Six were identified with the help of the District Six Museum and ex-residents. These sites were spatially archived. Stories of ex-residents were recorded and linked to the spatial archive. The locations of important destroyed sites were calculated, and were marked out on the ground, in situ. Time series animated mapping was compared with static mapping of District Six (Dawood \& Motala, 2015). In this article, we analyze the practice of finding and temporarily marking out the locations of destroyed sites. We propose that this practice, in combination with walks on contested lands such as District Six, be called counter-surveying.

In 2019, Vivienne suggested that Siddique take a group of conference attendees for a walk of District Six. The conference theme was related to hauntology, memory, and nostalgia. We decided to combine old and new maps of District Six, and to take people on a route that went past some sites that still exist and others that don't physically exist but remain as hauntings. The addition of old maps and photographs to the walks produced counter-cartographic experiences that were deeply affective.

\section{Counter-Surveying Diffracted}

The introduction of walking and storytelling into the sedimented engineering education curriculum provided us with inspiration and opportunity for deterritorialization. In particular, we are interested in the potential of subverting traditional practices of surveying, mapping, and archiving to embrace a counter-orientation. Our practices are microinstances of activism that open up creative possibilities. This is especially important in engineering education, which is grounded in positivist and quantitative logic. In addition, the engineering education assemblage in South Africa is shot through with power relations that are situated at a unique intersection of race, place, and inequality.

Focusing on individual stories and their entanglements counters the erasure of the complexities of lives. This erasure was due partly to the fact that the destruction wreaked on District Six was massive, and the sheer number of stories of dispossession paradoxically renders individuals invisible. As McKittrick (2006) notes, it is crucial to pay attention to "past erasure and objectification of subaltern subjectivities, stories, and lands" (p. x). We are similarly observing the anonymization of victims of the Covid-19 pandemic, because individual stories get buried among a deluge of bad news. As Bhattacharya (2019) suggests, communal healing should be a priority as we traverse multiple worlds, whether they be academia or the physical space of Cape Town. We wish to work with a sensibility that does justice to dispossessed people's stories, that respects their knowledge, and decenters colonial knowledge agendas. By working with micro-instances of activism, we are advocating for a practice that is similar to the practice of "autonomous mapping" that was proposed by the Counter Cartographies Collective et al. (2012), who describe it as "a mapping of and for political change without the aim of becoming a singular, dominating (cartographic) power" (p. 440).

Counter-surveying is an exercise in disidentification from the colonial surveyor or the purely technical surveyor (which, as we have noted, is a myth). Counter-surveying utilizes traditional surveying techniques, but has some fundamental differences, thus allowing it to have the "counter-" prefix. Traditional surveying practice in South Africa manifests in different forms, but the most common types of surveying done by surveyors are cadastral surveying and engineering surveying. Cadastral surveyors are deeply implicated in the system of land ownership, with its problematic colonial and capitalist underpinnings. Despite the 
conscious efforts by the ANC-led government in post-apartheid land reform, most of the race-based spatial boundaries still exist in South African cities and towns. Land reform initiatives are failing (Hull \& Whittal, 2017), and the reasons are multiple. These include a lack of political will by the government, seemingly contradictory viewpoints enshrined in the Constitution, cumbersome legal processes, and, more generally, the neoliberal economic environment (Ntsebeza, 2011). Usually, engineering surveyors produce topographic maps that are used to plan a structure, mark out its location on the ground, and monitor the construction.

Both cadastral and engineering surveying are done within rigid legislative frameworks, and ultimately serve to propagate the status quo. Springgay and Truman (2018) problematize the detached theorization of the racialization of space and remind us that traditional surveying and mapping could normalize the erasure of Black subjects. In counter-surveying, the physical demarcation of a site is done temporarily, and is done mainly for the benefit of dispossessed or disenfranchised people. By focusing on the Other, we are subverting traditional humanist power relations.

A diffractive reading of the practices of counter-surveying, counter-archiving, and counter-mapping shows resonances and dissonances between them. For Springgay, Truman, and Maclean (2019),

Counter-archiving and anarchiving practices are political, resistant, and collective. They disrupt conventional narratives and histories and seek ways to engage with matter not typically found in official archives and the affective experiences and lived histories of human and more-than human bodies. (p. 2)

Counter-surveying is done in the same vein as counterarchiving, with a view to affirmative horizons of hope. We are less interested in the documentation of past events, and more on processes, micro-political acts, and becomings (Manning, 2020; Massumi, 2016). An important aspect of counter-surveying is the use of counter-mapping techniques.

The term "counter-mapping" was first used by Nancy Peluso (1995) to describe mapping work that challenges maps made by government and corporate authorities. Counter-mapping is political and seeks to reveal the hegemonic politics in such maps (Rundstrom, 2009). Our counter-surveying practice takes seriously the scientific method of geomatics, but applies it in new ways that challenge the silencing and erasure typically associated with traditional maps. By showing the locations of Rose-Anne and Joe's ancestral homes over the current landscape, we are challenging their erasure. It should be noted that such acts of challenge, with respect to mapping, are not new.

The early 1990s saw a rise in the development of GIS for social justice activism. Activists combined GIS with new technologies to represent hegemonic abuses in new ways.
These abuses were those especially related to land and Indigenous peoples, such as visualizations of dispossession (e.g., mapping of apartheid group areas) and mapping of resource extraction (such as mining activities on the lands of Indigenous people). These factors contributed to countermapping practices being taken up by Indigenous people around the world in forms of postcolonial politics. Participatory GIS (PGIS) integrates local knowledge and stakeholder perspectives and is a mapping practice that has gained traction (Musungu et al., 2011). PGIS is a form of counter-mapping because it is bottom-up and ostensibly reflects the will of Indigenous people or the poor. Springgay and Truman (2018) also acknowledge the contribution of artists and social science researchers who "deploy countercartographical approaches to map against dominant power structures, question the assumptions that conventional maps produce, and recognize different spatial knowledge systems" (p. 99).

A dissonance between counter-archiving, counter-cartography, and counter-surveying is that counter-surveying focuses less on permanence-It is more of an ephemeral process that requires an embodied immersion. The process of walking is thus crucial to counter-surveying, and the end result of a counter-survey may be no physical artifacts at all. The traces are affective and could lead to new sensibilities and encourage new forms of activism and pedagogy. This is unlike counter-cartography, which relies on the production of a map. However, there is much overlap between the practices, and we utilize the Deleuzian logic of "and ... and ... and ..." (Deleuze \& Parnet, 1987) to conceptualize this new practice.

Contrary to the traditional geomatics conception, surveying and mapping can also be viewed as performances. The voice of humanism is privileged in the traditional geomatics conception of the world. The figure of the surveyor evolved out of a contingent array of historical processes. This figure is humanist and subtly anthropocentric (Motala, in press). The cartographic record of colonies such as South Africa shows us that surveyors/cartographers, through their maps, helped to create the myths of empire. Harley (2009) notes that "[s]urveyors marched alongside soldiers, initially mapping for reconnaissance, then for general information, and eventually as a tool of pacification, civilization, and exploitation in the defined colonies" (p. 132). Furthermore, colonial maps simultaneously contained and produced colonial subjects. There is a genealogical connection between war, colonization, cartography, and control. Garuba (2002) sums it up succinctly: "The surveillance and control of land, body and subject was the object of colonial geographies and, in securing this objective, the map as text, as model, as document and as claim was central to its project" (p. 87).

Harley notes that maps can speak volumes by their silence. Like feminist philosophers (see, for example, Barad, 2017; Braidotti, 2006; Spivak, 1996), he points out 
that silencing is an important aspect to note, so as to learn about the Other. Urban maps, for example, are not at the human scale and do not contain information about the quality of human life-The differential between the quality of White life and the life of Others in South Africa is stark. There is a qualitative shortcoming of maps to describe the human experience. Furthermore, mapping as we know it follows the Western paradigm of placing boundaries around "resources." These resources also included Indigenous people, who were viewed as raw material to be exploited (Mbembe, 2001).

\section{The Walks}

Although the practice emerged out of the seemingly objective discipline of geomatics, it eventually demanded an "embodied immersion in history and affective response [which] is a reversal of the archival mechanism of neutral, pseudo objective analysis" (Springgay et al., 2019, p. 4). Although there have been many walks that we have taken part in and facilitated, we will report on two here. The walks are illustrative of our theorization and development of counter-surveying as a methodology and micro-political activism.

We take seriously Tuck and Gaztambide-Fernández's (2013) challenge of doing pedagogical work that works against the curricular project of replacement. Siddique observed that the geomatics curriculum continued to "absorb, silence, and replace the non-white other, perpetuating white supremacy and settlerhood" (Tuck \& Gaztambide-Fernández, 2013, p. 73). We thus introduced the embodied practice of visiting the site of District Six (for geomatics students and other interested people), and ensured that the stories of displaced Black people featured prominently in our walking, teaching, and research.

\section{The Walk With Joe}

The first walk took place with Joe, Siddique, and three of Joe's immediate family - his mother, brother, and brother's wife. Joe is a filmmaker from England whose grandfather was from District Six-He was born at 16 Virginia Street and left South Africa for England in 1952, before his house was demolished. Joe is currently making a film that attempts to tell part of his grandfather's story. He explained,

In 2019, my grandfather, now at the age of 86 said that he wanted to go back to South Africa (possibly for the last time), so my brother and I jumped at the chance to go with and I wanted to use the trip to understand more about where my grandfather had come from and the history that I was connected to along my maternal line.

Joe contacted Siddique before coming to Cape Town in January 2020, and the idea of finding the exact location of the Virginia Street house was suggested, together with a walk of the District. Siddique calculated the geographic coordinates of the corner points of the property, and on the day of the walk, physically marked them with surveying poles.

Figure 3 (top) shows Joe's mother, Joe, and his brother inspecting the site of 16 Virginia Street. In the background are school children getting into minibus taxis, which will transport them home. The schools nearby are attended predominantly by Black children, who live in townships on the outskirts of Cape Town. Their daily existence of commuting from township ${ }^{1}$ to city is a result of the legacy of apartheid. Furthermore, and despite claimed attempts at desegregation of the city by authorities, gentrification keeps pushing working-class citizens further away (Garside, 1993).

Once the house was walked through, the poles were removed, leaving no traces of our physical presence on the landscape. The invisible traces of the event produced by counter-surveying are in antithesis to traditional surveying, which captures and marks the land.

\section{Joe}

We went to the site of the New Apostolic church which stands surrounded by rubble and earth almost exactly opposite where my grandfather's house would have been. We walked along Upper Constitution Street ending at the Tree of Remembrance.

The Tree of Remembrance and two other palm trees made an impression on Joe. Their presence drew us to them on the walks. The Tree of Remembrance is located on a rubble-strewn city block which contains no houses; there are only the remains of streets nearby. It was planted from seed by Ghadija Jamie in a flower box in front of her house in Milton Street in 1949. The seed was from a date, brought to Cape Town from Mecca by someone who would have visited the holy land as a pilgrim.

Figure 4 (left) shows the little date palm growing in the front of the house. This is what it looked like when it was young, contained in a building. It would be freed about two decades later, when the humans were moved and the building demolished. Amazingly, the tree survived the destruction of its house, and is still living today. All the other buildings in the vicinity would be demolished too, except for a row of houses on Upper Constitution Street about 50 meters away. These houses were left standing because White people were living there. The Tree of Remembrance is shown in Figure 4 (right), and the houses behind it are those on Upper Constitution Street. In the foreground is the rubble of the destroyed houses. The tree is the largest living thing in the vicinity today, with some homeless people taking shelter under it. These people are the new generation of dwellers of District Six who hold no security of tenure and are likely to be forcibly removed. The ghosts of forced 

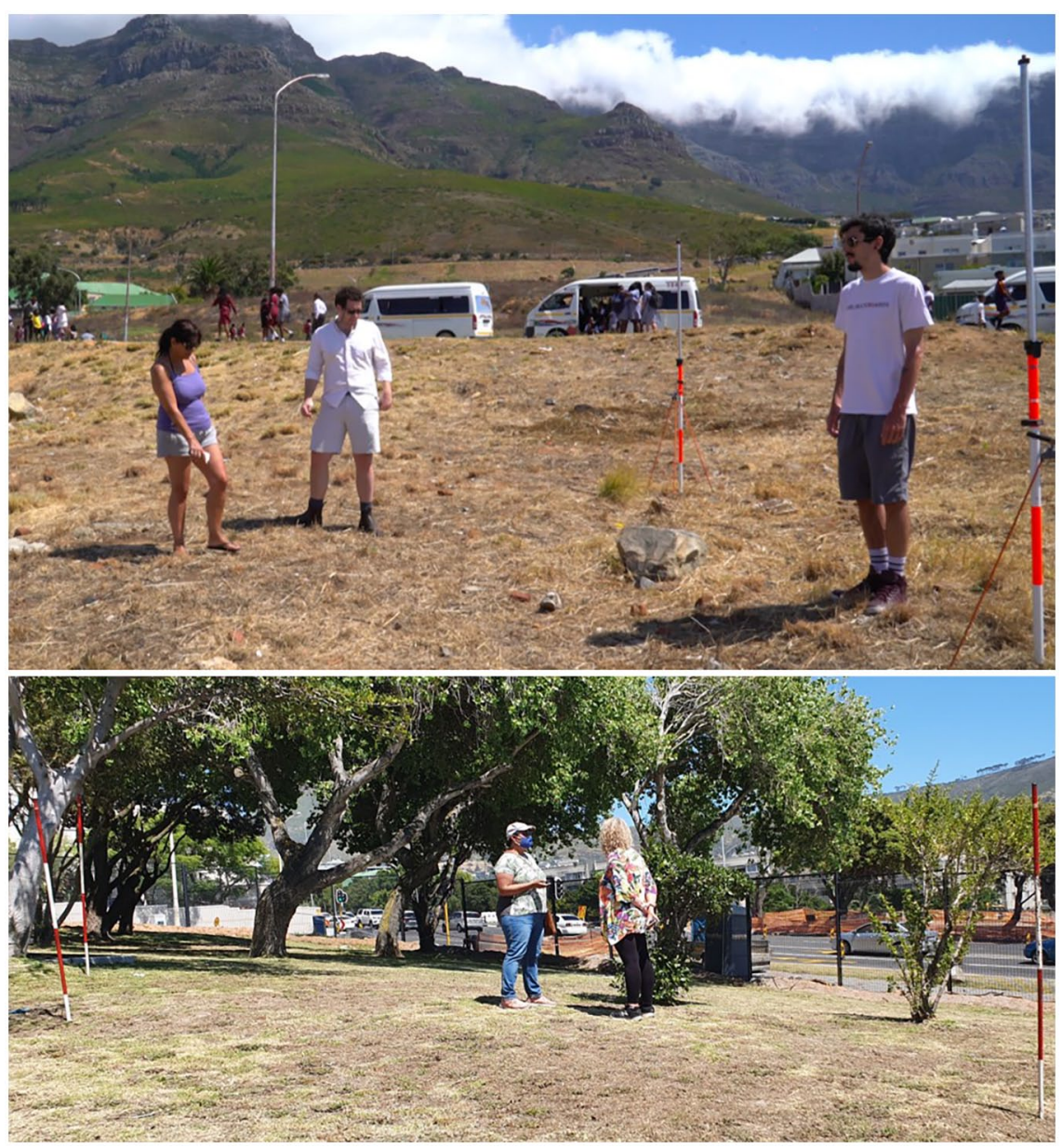

Figure 3. The sites of 16 Virginia street (top) and 7 De Villiers street (bottom).

removals haunt this tree, as it haunts the landscape, and it threads together a series of times before, during, and after demolitions.

It is also worthwhile to note that there is a break in the continuity of the living land, as is generally the case when urban development takes place over rural land. However, the destruction of District Six left open land in its wake. This open land surprisingly was not overtaken by much Indigenous vegetation, which occurs in abundance on Table Mountain nearby. This is even though the demolitions took place over three decades ago. For example, very few large trees survived the destruction of District Six. Being near Table Mountain, District Six is an ironic scar on the mountain which is the very heart of the Cape Floral Kingdom, a unique megadiverse ecological wonder.

In settler-colonial countries like South Africa, what is referred to as modernization or economic growth through land use simply serves to reproduce the hegemonic system and it effectively becomes the "usurper of ecosystems and local cultures" (Sato et al., 2014, p. 105). South Africa is a rapidly urbanizing country, and such development serves to make the landscape inhospitable for local fauna and flora. This was evident on our walk past the Tree of Remembrance, which is one of the very few trees that survived the violence meted out on several Others (the environment and humans of color) by the apartheid state.

When we visited 16 Virginia Street, the counter-surveying revealed the remains of walls of the building, in situ. The inset on Figure 2 shows the house in 1968, before it was demolished. Seeing the physical remains of his ancestral home was meaningful for Joe. He said,

You could still make out the outlines of the original walls just underneath the overgrown grass and how the bricks ripped from the destroyed houses had laid there for thirty or forty years until we arrived and collected a couple as a kind of strange souvenir. We spent time standing on what would have been his stoep, looking left at the church and right toward Table Mountain, 


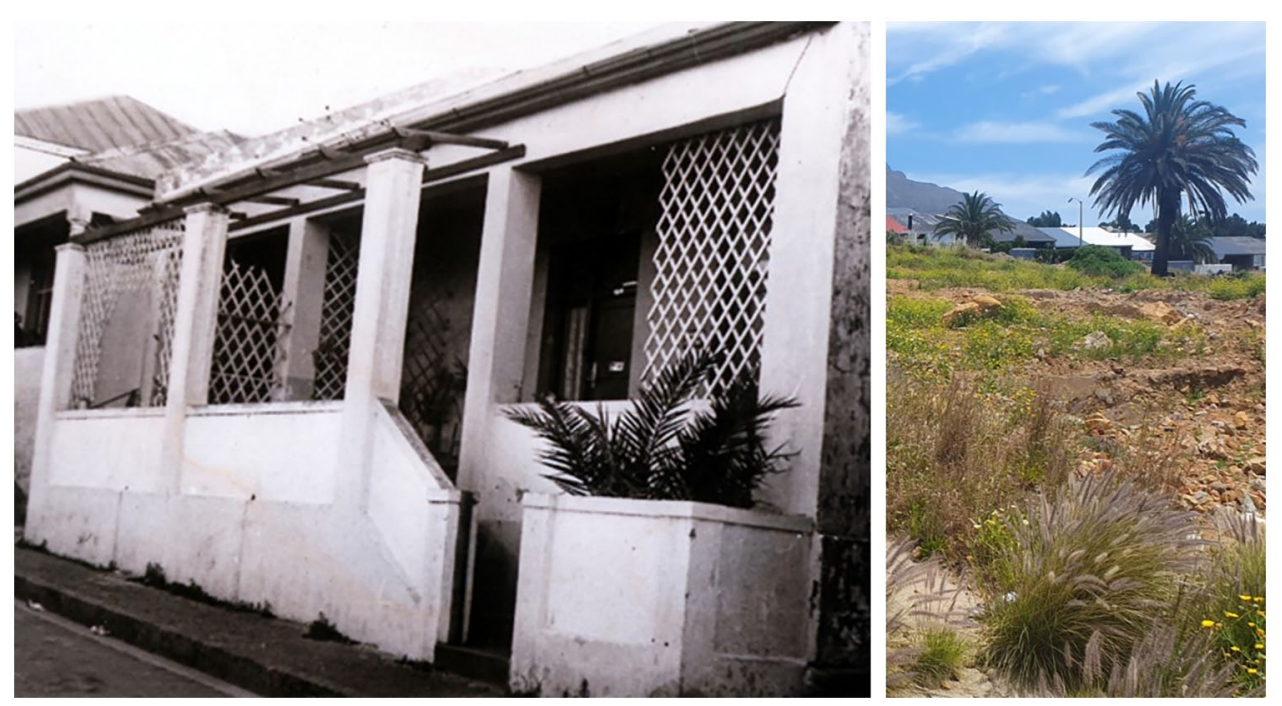

Figure 4. The Tree of Remembrance in the 1950s (left) and today (right). Note. Left image credit: Suleiman Christians, District Six Museum Archive.

trying to imagine roads, houses, cars, people walking, laying out washing, the smells of cooking, music coming from radios, and feeling it all in stark contrast to the barren emptiness of the afternoon sun on scorched grass.

In addition, Joe's mother pointed out,

I felt a strong connection to my father and his parents and the life they had in District Six, I have pictures of my dad and his family in the 1930s on the church steps.

The trees, the church, the children, and the rubble provided an immersion into a unique and personal experience for the family. It brought up affective responses, together with new thoughts about land restitution, conservation, and education. The process of walking and noticing are a crucial part of counter-surveying. The immersion in the landscape and exposure to the ghosts of District Six was a micro-political act for all present, as the intangible traces are likely to be reactivated in future.

\section{The Walk With Rose-Anne}

Rose-Anne's mother lived at 7 De Villiers Street until the house was demolished in 1968 and they were forcibly removed to various neighborhoods across Cape Town. Rose-Anne grew up in Belhar, a designated Colored group area approximately $20 \mathrm{~km}$ away from District Six. The house was a large double-story semi-detached dwelling that was bordered by De Villiers Street in the front. The inset on Figure 2 shows the house in 1968, just before it was demolished. Rose-Anne's mother and her eight siblings were born and grew up here. The pain of being forced to leave this special place and cosmopolitan community is still felt by many, and both Rose-Anne's mother and Joe's grandfather attest to this. Rose-Anne's mother feels tired of telling onesided stories of District Six that focus on the forced removals only. While this was an important event, and one that invariably brings forth pain, Rose-Anne points out that this erases the complexity of life as a District Sixer, and casts ex-residents as victims only. Both Rose-Anne's mother and Joe's grandfather chose not to be present at the demarcation of their childhood homes. Memories are written into the world, and as we have noted elsewhere, the "ghosts which linger in District Six exert an impact on everyday life of those who traverse this territory in the center of Cape Town, impacting the taken-for-granted realities of the past, present and future of the city" (Zembylas et al., 2020, p. 27).

Using counter-surveying, Siddique calculated the location of the ghost house and placed poles to mark the locations of the corner beacons temporarily. Figure 3 (bottom) shows Rose-Anne and Vivienne standing where the house would have been. The house was walked through and after a discussion, the poles removed. This experience had a profound effect on Rose-Anne, and she cried when she saw the poles that marked out the location of her mother's house.

After the demolitions, some schools, churches, and mosques were perversely left behind-Although they were bricks and mortar, they were differently marked and survived. These surviving buildings played an important role in the lives of the Black bodies who were removed from District Six. We see in Rose-Anne's story that long after all the other buildings were gone, her family returned to their 
church in District Six. Rose-Anne came to school in District Six, even though she lived in Belhar, some $20 \mathrm{~km}$ away. Schools and churches are the ghostly remnants of District Six and exert an attraction on residents. The binary concept of here-there is troubled by Rose-Anne. As she walked over the ghost of the house, she alluded to the complexity of multilocality:

When we talk about being in this place; the wind blows to us in Belhar (where we lived). So when I'm walking here, I'm walking in Belhar, I'm walking in Kensington, I'm walking in Fairways $^{2}$ where my family had to go to. I'm here but I'm walking into Greenmarket Square and the racism that we experienced, ${ }^{3}$ and the joy that was here.

In District Six, the schools that are still operating today have an excellent reputation and a proud anti-apartheid heritage. Many people at Vivienne's institution, which is a historically Black university, who occupy or have occupied leadership positions had attended one of these schools. The schools have maintained their intellectual rigor, and produced some of the leading political, artistic, and scientific minds in South Africa.

\section{Vivienne}

I was feeling awkward as the "settler" in the group and wondering what place I had being there, listening to RoseAnne's story and witnessing the way Siddique had staked out her mom's house. It was situated at a strange angle to the now established hulking monstrosity of concrete which is CPUT. Being in the field of higher education what was staying with me was the callousness of establishing a White university slapbang in the middle of the most prominent area of forced removals in central Cape Town. I felt privileged to share in such an intimate experience with Rose-Anne and felt that I learnt a lot of new things in a tactile way with Siddique and Rose-Anne's assistance.

We set off from the house, past several sites, then on to the location of the Tafelberg Hotel remains. The area is currently being cleared for housing, and the walls and floors of the Tafelberg Hotel were clearly visible. Seeing the exposed walls and floors of the hotel brought back the ghosts of many who frequented it. The hotel was an important multiracial meeting place in District Six, and features in the stories of many District Sixers. Joe says,

District Six sounds like it may have been one of the most progressive places in the world during the first half of the twentieth century. Stories of mixing races, cultures and religions, living side by side and synergizing from the experience are rare from that time in history.

Although the destruction of District Six emerged out of colonial logic - the valuable African land was claimed by the powerful White government and the residents were forcibly removed - it did not necessarily aid nor guarantee settler futurity in the immediate aftermath. Seen from the point of view of the colonized, the destruction is an ongoing act of violence that continues to tear communities apart and keep people away. Yet District Six was also seen by many White South Africans as salted earth, a contentious place that was haunted with pain and conflict, so the replacement of Black bodies by White bodies never happened on a scale that was originally envisaged. Instead, Cape Technikon, a White higher education institution which later became CPUT, was built as an afterthought. Even though the process of land reform is moving slowly, what continues in District Six is an ongoing emplacement of settler futurity and anthropocentrism, premised on the logics of the market. We walked over the rubble of houses, and we know that a new generation of District Sixers will settle here. Will District Six once again become the cosmopolitan and progressive place that it once was, a place that embodied the positivity of difference? We hope so, yet our walk is foreboding. This beautiful piece of land, situated between the ancient mountain and the ocean, is valuable because of its location. It has always been haunted by the ghosts of manythe ancient Khoi; the colonizing Dutch and British; the working-class and enslaved settlers from India, Indonesia, Malaysia, Madagascar, and East Africa; the imported flora (some still stand defiant); the critically endangered endemic plants and animals of the shrinking biodiverse Cape Floral Region; and the people who were forced away from here.

\section{Propositions}

Propositions are what Manning and Massumi (2014), following Whitehead (1978), refer to as inflections or forces that influence what may come to be expressed in process. Through attunement and invention, propositions bring out potential for transformation (Manning, 2020). They look tentatively at what could be, and ask speculative questions - such as what is the new that activating counter-surveying, counter-mapping, and anarchiving practices could bring to the situation? What interesting alternative potentialities might be activated and made possible by these practices? As Truman and Springgay (2016) explain, "Propositions do not give information as to how they function in concrete instances but gesture to how they could potentialize" (p. 259).

In the propositions which follow, it is important to bear in mind that they do not assume a volitional and intentional human agent-They exceed the individual. It is rather in events and relationships, and more particularly in the inbetween or interstices, that potentials come into being. As Manning (2020) notes, "in the Whiteheadian sense, they are 
lures for feeling: they excite the transversal orientation of a set of conditions ripe for the reorienting" (p. 171).

\section{Proposition I: Counter-Surveying}

In this article, we introduce and propose the concept of counter-surveying. It is a type of surveying which emerges out of the science of geomatics and is informed by a posthumanist sensibility. It manifests performatively in a similar way as traditional surveying, but does not focus on permanence. Counter-surveying creates temporary marks on the land that also leave "marks on bodies" (Barad, 2007). It consists of micro-instances of activism and offers possibilities for exploration, creativity, walking, critique, and respectful mappings from multiple perspectives. It is informed by non-representational theory and is a work in progress. We feel that this proposition is a provocation to continue this type of work, with a focus on the ephemeral nature of counter-surveying as performance, and on the im/ permanent marks on bodies that it leaves behind.

Counter-surveying has a lot in common with counterarchiving and counter-mapping. The point of counter-surveying is not to document from an archive, and not to re-present existing geographies. Rather, it is a political and collective practice leading to resistance, through disrupting conventional narratives and histories. The official archive often states the fact that 60,000 people were removed from District Six. While this is true, it erases the ongoing effects on lives. The impermanent marking out of the ghosts of houses in District Six allowed the pain of the past/present/future to seep through, foregrounding the singularity of experience.

Counter-surveying also does not assume that the surveyor/cartographer is the expert, placed in a hierarchical relationship with others. In the case of our walks with RoseAnne and Joe, they guided us, we guided them, and District Six itself directed our meanderings in an immanent process which produced a fleeting yet powerful experience. When considering its value as pedagogy, it produces local knowledge which does not aim to be included in the singular and dominant canon, thus taking a decolonizing path. The inclusion of walking-with in counter-surveying develops a type of collective thinking between humans, the land and destroyed buildings. This produces traces which may be reactivated in future encounters, thus facilitating a past/ present/future perspective.

\section{Proposition 2: For Some Worlds}

"It requires the risk of being for some worlds rather than others and helping to compose those worlds with others" (Haraway, 2016, p. 178).

Guided by a posthumanist ethic, we are committed to building relations with alterity. Therefore, the worlds we are for are those of what Braidotti (2013) calls the racialized, sexualized, and naturalized others, and refer to people of color, women, animals, and non-living matter. We stand in solidarity with the people who were removed, and being educators, we realize the importance of resisting what Tuck and Gaztambide-Fernández (2013) call the "settler-colonial curricular project of replacement" (p. 73). We offer resistance through walking by joining subjugated knowledges (Foucault, 1980) with counter-surveying.

As researchers, we stand in solidarity with people like Rose-Anne, Joe, and their families past and present. We acknowledge that we don't necessarily have to bear the labor (emotional, intellectual, and physical) that they are compelled to experience. Taking differently positioned people on walks of District Six is a way of confronting privileged irresponsibility ${ }^{4}$ (Bozalek, 2014). We also sent an initial version of this article to Rose-Anne and Joe, who made important contributions and suggestions.

By counter-surveying the houses of ex-residents, we are continuing to tell their stories when they might not be able to. Students who took part in our ongoing District Six research were participating in what we call a pedagogy of hauntology (Zembylas et al., 2020). This pedagogy, and the walks of District Six, can help us to potentiate ways to take responsibility for the appearance of the ghosts of apartheid, such as showing the absurdity of the actions of the apartheid state. We do this by deploying the very techniques and technologies that apartheid and colonization used, but toward the aim of subversion. We are telling the story of the Other through embodied hauntologies (Gordon, 2008) by bringing people to this mythical place and walking across disciplines with atmospheres and absences/presences. We are always on the move, yet try to stay in the in-between space: between disciplines, between generations, between past/ present/futures, and between here/there.

The walks remind us of the importance of taking an anti-humanist and anti-anthropocentric stance. Even though the return of the dispossessed people of District Six is taking place slowly, it is a welcome change to the stasis that has plagued District Six for decades. We wonder if more can and should be done to celebrate and promote the ecological diversity of Table Mountain, of which District Six is a part. The large trees that dot the landscape called out to us and reminded us of ghosts. Many District Six stories that we have heard over the years contain Cape flora, mountain streams, caves, dogs, squirrels, rats, and Table Mountain stone-These made appearances or haunted our walks of the site.

\section{Conclusion}

Despite (or because of) our different legacies and trajectories, we have come together to work across difference to think differently about the past/present/future. Many of the 
societal problems that South African society faces today can be hauntologically connected to places like District Six, whose social and material fabric was torn apart. By attending to the ghosts of District Six, we explore different ways of interrogating issues of land, curriculum, education, recuperation, and giving space to Otherness. The counter-surveying and walking make such presences felt, seeping into the thick now of present time, revealing aspects of the effects of hidden social, environmental, and systemic structures (Gordon, 2008). We feel that the embodied transdisciplinary and transgenerational activism allowed by counter-surveying should be ongoing. This works toward a justice to come (Bozalek et al., 2021).

The process of mapping then surveying the haunted houses is deeply affective. Moments of intense emotion emerge from combining technology, counter-mapping, counter-surveying, history, local place, and performance. In this process of affecting and being affected (Massumi, 2015), mapping is reimagined as a practice that is not exclusively representational, as is conventionally thought, but as a way of casting oneself for some worlds and not for others.

\section{Acknowledgments}

Thanks to Rose-Anne Reynolds and Joe Ridout, our fellow walkers.

\section{Declaration of Conflicting Interests}

The author(s) declared no potential conflicts of interest with respect to the research, authorship, and/or publication of this article.

\section{Funding}

The author(s) disclosed receipt of the following financial support for the research, authorship, and/or publication of this article: This work is based on the research supported in part by the National Research Foundation of South Africa (Grant Number: 120845).

\section{ORCID iDs}

Siddique Motala (iD https://orcid.org/0000-0002-9679-6175

Vivienne Bozalek (iD https://orcid.org/0000-0002-3212-1910

\section{Notes}

1. A suburb of predominantly Black occupation, formerly officially designated for Black occupation by apartheid legislation.

2. Belhar, Kensington, and Fairways are residential areas to which people classified as Colored under apartheid legislation were forcibly removed to.

3. When the Methodist Church in District Six (Rose-Anne's church) was turned into the District Six Museum in 1988, a decision was made to amalgamate with the Central Methodist Church, a mainly White church in Greenmarket Square nearby. Rose-Anne described the significance of walking from the Methodist Church, which contained a lively, cosmopolitan congregation that vehemently opposed apartheid, to the Central Methodist Church, where she experienced racism.

4. A term coined by Joan Tronto, referring to the phenomenon of how a dominant group fails to acknowledge their exercise of power and maintenance of hegemony, thus taking for granted their position of privilege.

\section{References}

Barad, K. (2007). Meeting the universe halfway: Quantum physics and the entanglement of matter and meaning. Duke University Press.

Barad, K. (2017). Troubling time/s and ecologies of nothingness: Re-turning, re-membering, and facing the incalculable. New Formations: A Journal of Culture/Theory/Politics, 92, 56-86.

Bhattacharya, K. (2019). (Un)Settling imagined lands: A par/ des(i) approach to de/colonizing methodologies. In P. Leavy (Ed.), The Oxford handbook of methods for public scholarship (pp. 175-208). Oxford University Press.

Bozalek, V. (2014). Privileged irresponsibility. In G. Olthuis, H. Kohlen, \& J. Heier (Eds.), Moral boundaries redrawn: The significance of Joan Tronto's argument for political theory, professional ethics, and ethics of care (pp. 51-72). Peeters.

Bozalek, V., Zembylas, M., Motala, S., \& Hölscher, D. (2021). Higher education hauntologies: Living with ghosts for a justice-to-come. Routledge.

Braidotti, R. (2002). Metamorphoses: Towards a materialist theory of becoming. Polity Press.

Braidotti, R. (2006). Transpositions: On nomadic ethics. Polity Press.

Braidotti, R. (2013). The posthuman. Polity Press.

Counter Cartographies Collective, Dalton, C., \& Mason-Deese, L. (2012). Counter (mapping) actions: Mapping as militant research. ACME, 11(3), 439-446.

Dawood, N., \& Motala, S. (2015). Evaluating an animated and static time series map of District Six: A visual and cognitive approach. South African Journal of Geomatics, 4(3), 189197. https://doi.org/10.4314/sajg.v4i3.1

Deleuze, G., \& Parnet, C. (1987). Dialogues (H. Tomlinson \& B. Habberjam, Trans.). Athlone Press.

Edney, M. H. (2011). Cartography without "progress": Reinterpreting the nature and historical development of map making. In M. Dodge (Ed.), Classics in cartography: Reflections on influential articles from cartographica (pp. 305-329). Wiley-Blackwell.

Foucault, M. (1980). Power/knowledge: Selected interviews and other writings. Pantheon Books.

Garside, J. (1993). Inner city gentrification in South Africa: The case of Woodstock, Cape Town. Geojournal, 30(1), 29-35.

Garuba, H. (2002). Mapping the land/body/subject: Colonial and postcolonial geographies in African narrative. Alternation, 9(1), 87-116.

Gordon, A. F. (2008). Ghostly matters: Haunting and the sociological imagination. University of Minnesota Press.

Haraway, D. (2016). Staying with the trouble: Making kin in the Chthulucene. Duke University Press.

Harley, J. B. (1990). Cartography, ethics and social theory. Cartographica, 27(2), 1-23. https://doi.org/10.3138/C2111512-0603-XJ14 
Harley, J. B. (2009). Maps, knowledge, and power. In G. Henderson \& M. Waterstone (Eds.), Geographic thought: A praxis perspective (pp. 129-148). Routledge.

Hull, S., \& Whittal, J. (2017). Human rights in tension: Guiding cadastral systems development in customary land rights contexts. Survey Review, 51(4), 1-17. https://doi.org/10.1080/00 396265.2017 .1381396

MacLure, M. (2013). Researching without representation? Language and materiality in post-qualitative methodology. International Journal of Qualitative Studies in Education, 26(6), 658-667. https://doi.org/10.1080/09518398.2013.788755

Manning, E. (2020). For a pragmatics of the useless. Duke University Press.

Manning, E., \& Massumi, B. (2014). Thought in the act. University of Minnesota Press.

Massumi, B. (2015). Politics of affect. Polity Press.

Massumi, B. (2016). Working principles. In A. Murphie (Ed.), The go-to how to book of anarchiving: Senselab and the distributing the insensible event (pp. 6-9). Concordia University.

Mbembe, A. (2001). On the postcolony. University of California Press.

McKittrick, K. (2006). Demonic grounds: Black women and cartographies of struggle. University of Minnesota Press.

Motala, S. (in press). The two cartographies: A posthumanist approach to geomatics education. In R. Dolphijn \& R. Braidotti (Eds.), Deleuze and Guattari and fascism. Edinburgh University Press.

Musungu, K., Motala, S., \& Smit, J. (2011). A participatory approach to data collection for GIS for flood risk management in informal settlements of Cape Town. In AfricaGEO 2011 Conference Proceedings, Cape Town, South Africa, 31 May-2 June.

National Geo-Spatial Information. (n.d.). What is cartography. http://www.ngi.gov.za/index.php/technical-information/ catography/what-is-cartography

Ntsebeza, L. (2011). The land question: Exploring obstacles to land redistribution in South Africa. In I. Shapiro \& K. Tebeau (Eds.), After apartheid: Reinventing South Africa (pp. 294 308). University of Virginia Press.

Peluso, N. L. (1995). Whose woods are these? Counter-mapping forest territories in Kalimantan, Indonesia. Antipode, 27, 383-406.

Rundstrom, R. (2009). Counter-mapping. In A. Kobayashi (Ed.), International Encyclopedia of human geography (pp. 314 318). Elsevier.
Sato, M., Silva, R., \& Jaber, M. (2014). Between the remnants of colonialism and the insurgence of self-narrative in constructing participatory social maps: Towards a land education methodology. Environmental Education Research, 20(1), 102-114. https://doi.org/10.1080/13504622.2013.8 52654

Spivak, G. C. (1996). The Spivak reader: Selected works of Gayatri Chakravorty Spivak (D. Landry \& G. MacLean, Eds.). Routledge.

Springgay, S., \& Truman, S. (2018). Walking methodologies in a more-than-human world: Walkinglab. Routledge.

Springgay, S., Truman, A., \& MacLean, S. (2019). Socially engaged art, experimental pedagogies, and anarchiving as research-creation. Qualitative Inquiry, 26(7), 897-907. https://doi.org/10.1177/1077800419884964

Thrift, N. (2008). Non-representational theory: Space/politics/ affect. Routledge.

Truman, S. E., \& Springgay, S. (2016). Propositions for walking research. In K. Powell, P. Bernard, \& L. Mackinley (Eds.), International handbook for intercultural arts (pp. 259-267). Routledge.

Tuck, E., \& Gaztambide-Fernández, R. A. (2013). Curriculum, replacement, and settler futurity. Journal of Curriculum Theorizing, 29(1), 72-89.

Whitehead, A. N. (1978). Process and reality. The Free Press.

Zembylas, M., Bozalek, V., \& Motala, S. (2020). A pedagogy of hauntology: Decolonizing the curriculum with GIS. Capacious Journal for Emerging Affect Enquiry, 1(5), 26-48. https://doi.org/10.22387/CAP2019.35

\section{Author Biographies}

Siddique Motala $(\mathrm{PhD})$ is a Senior Lecturer in the Department of Civil Engineering at the University of Cape Town. His research is focused on posthumanism, GIS, urban infrastructure, spatio-temporal mapping and innovative practices in engineering education.

Vivienne Bozalek is an Emerita Professor of Women's and Gender Studies at the University of the Western Cape, and Honorary Professor in the Centre for Higher Education Research, Teaching and Learning (CHERTL) at Rhodes University, South Africa. Her research interests are in the areas of social justice and the political ethics of care perspectives, feminist and participatory research methodologies, posthumanism, feminist new materialist and critical family studies. 